\title{
Alpha-synuclein deficiency leads to increased glyoxalase I expression and glycation stress
}

\author{
Alexander Kurz • Naila Rabbani • Michael Walter • \\ Michael Bonin • Paul Thornalley • Georg Auburger • \\ Suzana Gispert
}

Received: 2 June 2010/Revised: 20 July 2010/Accepted: 28 July 2010/Published online: 14 August 2010 (C) The Author(s) 2010. This article is published with open access at Springerlink.com

\begin{abstract}
The presynaptic protein alpha-synuclein has received much attention because its gain-of-function is associated with Parkinson's disease. However, its physiological function is still poorly understood. We studied brain regions of knock-out mice at different ages with regard to consistent upregulations of the transcriptome and focused on glyoxalase I (GLO1). The microarray data were confirmed in qPCR, immunoblot, enzyme activity, and behavior analyses. GLO1 induction is a known protective cellular response to glucose stress, representing efforts to decrease toxic levels of methylglyoxal (MG), glyoxal and advanced glycation endproducts (AGEs). Mass spectrometry quantification demonstrated a ubiquitous increase in MG and fructosyl-lysine as consequences of glucose toxicity, and consistent enhancement of certain AGEs. Thus, GLO1 induction in KO brain seems insufficient to prevent AGE formation. In conclusion, the data demonstrate GLO1 expression and glycation damage to be induced by alphasynuclein ablation. We propose that wild-type alpha-synuclein modulates brain glucose metabolism.
\end{abstract}

A. Kurz · G. Auburger · S. Gispert ( $₫)$

Department of Neurology, Section Molecular Neurogenetics,

Bldg. 89, Goethe University Medical School,

Theodor Stern Kai 7, 60590 Frankfurt am Main, Germany

e-mail: gispert-sanchez@em.uni-frankfurt.de

N. Rabbani · P. Thornalley

Clinical Sciences Research Institute, Warwick Medical School,

University of Warwick, University Hospital,

Coventry CV2 2DX, UK

M. Walter · M. Bonin Institute of Medical Genetics, Eberhard Karls University, Tübingen, Germany
Keywords Alpha-synuclein deficiency · Transcriptome microarray · Glyoxalase I .

Advanced glycation endproducts - Glucose metabolism

$\begin{array}{ll}\text { Non-standard abbreviations } \\ \text { 3-DG } & \text { 3-deoxyglucosone } \\ \text { 3DG-H } & \text { Hydroimidazolones derived from } \\ & \text { 3-deoxyglucosone } \\ \text { 3-NT } & \text { 3-nitrotyrosine } \\ \text { AGE } & \text { Advanced glycation endproduct } \\ \text { CE } & \text { Collision energy } \\ \text { CEL } & \text { Ne-carboxyethyl-lysine } \\ \text { CMA } & \text { No-carboxymethyl-arginine } \\ \text { CMC } & \text { S-carboxymethyl-cysteine } \\ \text { CML } & \text { Ne-carboxymethyl-lysine } \\ \text { CV } & \text { Cone voltage } \\ \text { DETAPAC } & \text { Diethylenetriamine penta-acetic acid } \\ \text { DT } & \text { Dityrosine } \\ \text { FBPase } & \text { Fructose-1, 6-bisphosphatase } \\ \text { FL } & \text { Fructosyl-lysine } \\ \text { Gabrg2 } & \text { Gamma-aminobutyric acid (GABA-A) } \\ \text { GEO } & \text { receptor subunit gamma 2 } \\ \text { Gene Expression Omnibus } & \text { Hydroimidazolones derived from glyoxal } \\ \text { GLO1 } & \text { Glyoxalase 1 } \\ \text { LC-MS/MS } & \text { Liquid chromatography-tandem mass } \\ \text { spectrometry } \\ \text { LOD } & \text { Limit of detection } \\ \text { MetSO } & \begin{array}{l}\text { Methionine sulfoxide } \\ \text { Methylglyoxal }\end{array} \\ \text { MG-H1 } & \text { Hydroimidazolones derived from } \\ \text { methylglyoxal } \\ \text { NFK } & \text { MG-derived lysine dimer } \\ & \end{array}$




$\begin{array}{ll}\text { pnd } & \text { Postnatal day } \\ \text { qPCR } & \text { Quantitative real-time RT-PCR } \\ \text { RIPA } & \text { Radio immuno precipitation assay } \\ \text { SNCA } & \text { Alpha-synuclein } \\ \text { Tbp } & \text { TATA binding protein } \\ \text { TCA } & \text { Trichloroacetic acid } \\ \text { UPLC } & \text { Ultrahigh pressure liquid chromatography }\end{array}$

\section{Introduction}

Alpha-synuclein was initially described as a component of the extracellular protein aggregates characteristic for Alzheimer's disease (AD) [1]. Later, missense mutations and elevated gene dosage of the alpha-synuclein gene SNCA were found to cause rare autosomal dominant variants of Parkinson's disease (PD) with early manifestation [2, 3]. In the frequent sporadic old-age variant of PD, wild-type (WT) alpha-synuclein acquires gain-of-function properties, undergoes protein aggregation and forms cytoplasmic inclusions named Lewy bodies in the affected neurons [4]. With advancing age, this pathogenic process advances from the brainstem via the midbrain to involve eventually all cerebral regions including the primary neocortex [5]. This regional specificity may result from different metabolic demands, since most Parkinson-associated genes like alpha-synuclein are expressed quite ubiquitously. The affected tissue is characterized by a loss of glutathione and oxidative stress since presymptomatic stages [6]. With age, mutations in the mitochondrial genome accumulate, with impairment of respiratory complex I activity [7]. Mitochondrial dysfunction and alpha-synuclein aggregation characterize the degenerating neurons after a disease course of more than 30 years [8], while identical mutation effects have little degenerative effects after the 2-year lifespan of mouse models with overexpression of SNCA. In living patients, the neurodegenerative process of PD can be monitored through the documentation of reduced glucose utilization in affected brain regions by positron emission tomography [9].

However, the physiological function of alpha-synuclein is not well understood. Its expression is mainly in neurons and its localization is usually presynaptic [10]. Alphasynuclein was implicated in Golgi trafficking by complementation studies in yeast and C. elegans [11-14] and found in association with synaptic vesicles [15]. It was proposed to act as chaperone or inhibitor of the SNARE complex responsible for vesicle fusion and neurotransmitter release $[16,17]$. In mice with alpha-synuclein loss-offunction (SNCA-KO), a reduction of synaptic vesicles and neurotransmitter levels [18-21], altered neurotransmitter release $[22,23]$, selective changes in synaptic signaling proteins [24], altered synaptic plasticity [25], pathological lipid composition and respiratory activity of mitochondria [26] were reported. Thus, brain alpha-synuclein appears to exhibit important functions for synaptic transmission and maintenance, but the molecular interactions and mechanisms remain largely undefined.

In order to gain additional molecular insights into the physiological functions of alpha-synuclein in the aging nervous system, we employed young and old SNCA-KO mice to document the transcriptional profile of two quite homogeneous brain regions (striatum and cerebellum). An upregulation of glyoxalase I (GLO1), a highly conserved enzyme known to protect cells from glucose toxicity, was observed consistently. This induction was found insufficient to protect the tissue completely against glycation damage. Overall, the data suggest a prominent alteration of glucose metabolism in mouse brain by SNCA ablation.

\section{Materials and methods}

\section{Animals and housing}

Alpha-synuclein-deficient (knock-out, KO) mice with a targeted replacement of exons 4 and 5 of the SNCA gene [19] were compared to wild-type (WT) animals with the corresponding 129S6/SvEvTac background.

Mice were housed in Type II L cages $(365 \times$ $207 \times 140 \mathrm{~mm}$, floor area $530 \mathrm{~cm}^{2}$; IVC-based) in the same animal room (where the environmental temperature was maintained between 20 and $24^{\circ} \mathrm{C}$, humidity: $55 \pm$ $10 \%$ ) under $12 / 12 \mathrm{~h}$ light/dark cycle with food and water ad libitum.

All experiments employing mice were performed in compliance with the European Communities Council Directive of 24 November 1986 (86/609/EEC) and the National Institutes of Health Guide for the Care and Use of Laboratory Animals.

\section{Transcriptome analyses}

Three age groups were employed: mouse pups at the age of postnatal day 7 (pnd 7), young adult mice at the age of 6 months and old mice of at least 19 months of age. Following cervical dislocation of young adult and old mice, the brain was dissected into brainstem, midbrain, cerebellum, and striatum (dorsal and ventral striatum as a tissue block). In case of the mouse pups, the brain was dissected into both hemispheres. Immediately after dissection, the tissues were frozen in liquid nitrogen and stored at $-80^{\circ} \mathrm{C}$ until further analyses.

The data discussed in this publication have been deposited in NCBI's Gene Expression Omnibus [27] and 
are accessible through GEO series accession number GSE19534.

Transcriptome survey via oligonucleotide microarrays

From the brains of adult ( 6 months) versus old (21 months) male mice, striatal ( $n=3$ mutant vs. $n=3$ wild-type) and cerebellar ( $n=3$ vs. $n=4$ ) tissue was dissected, both for KO mice and for WT control animals. Double-stranded cDNA synthesized from $1 \mu \mathrm{g}$ of total RNA was linearly amplified and biotinylated using the One-Cycle Target Labeling Kit (Affymetrix; Santa Clara, CA, USA) according to the manufacturer's instructions.

Labeled and fragmented cRNA $(15 \mu \mathrm{g})$ was hybridized to MOE430 2.0 GeneChip $^{\circledR}$ arrays (Affymetrix). After hybridization, the arrays were washed and stained in a Fluidics Station 450 (Affymetrix) with the recommended washing procedure. Biotinylated cRNA bound to target molecules was detected with streptavidin-coupled phycoerithrin, biotinylated anti-streptavidin IgG antibodies and again streptavidin-coupled phycoerithrin according to the protocol. Arrays were scanned using the GCS3000 GeneChip scanner (Affymetrix) and GCOS 1.4 software. Scanned images were subjected to visual inspection to control for hybridization artifacts and proper grid alignment.

Linear models were applied to define the influence of the factor genotype on the transcriptome. For quality control, Genespring 7.3 (Agilent Technologies; Böblingen, Germany) and Expression Console (Affymetrix) were used. The data was mathematical-statistically assessed, visualized, and functionally correlated by employing the software platform $\mathrm{R}$ (version 2.5.0) and Bioconductor 2.0.8 [28] with the packages "affy" [29] and "limma" $[30,31]$ as well as the panther website (http://www. pantherdb.org).

Initially, the expression data from all chips were normalized with the RMA (Robust Multichip Average) method to yield log2-transformed signal values. Global gene expression was compared between chips using scatter plots and Pearson's R correlation coefficients. The signal values were then averaged for the individual subgroups and differences in expression level were calculated in $\log 2$ space ( $M$ values). Differences between subgroups were extracted as contrasts and analyzed with the moderated $F$ test (empirical Bayes method) including a correction step for multiple testing with the 5\%-FDRbased method of Benjamini and Hochberg. To attribute significant regulations to individual genes, a decision matrix was generated based on the function decide tests within the Limma option nestedF, where significant up- or downregulations are represented by values of 1 or -1 , respectively.
Transcript level assays via qPCR

Total RNA was extracted from brain hemispheres derived from mouse pups and from brainstem and midbrain derived from adult male mice with TRIZOL (Invitrogen; Karlsruhe, Germany) and digested with DNase (amplification grade I; Invitrogen) following the manufacturer's instructions. In case of the striata derived from 19-month-old male mice, RNeasy Lipid Tissue Mini Kit (Qiagen; Hilden, Germany) was used for RNA extraction. Then, $2 \mu \mathrm{g}$ of DNase-treated RNA were reverse-transcribed in a $36-\mu 1$ reaction, using $\operatorname{pd}(\mathrm{N})_{6}$ and NotI-d(T) 18 primers (First Strand cDNA Synthesis Kit; Amersham Biosciences; Freiburg, Germany).

For validation of Glol transcript levels, all qPCR reactions were carried out in a total volume of $20 \mu \mathrm{l}$ containing $5 \mu \mathrm{cDNA}$ template, $10 \mu \mathrm{l} 2 \times$ TaqMan $^{\circledR}$ Universal Master Mix (Applied Biosystems; Darmstadt, Germany) and $1 \mu \mathrm{l}$ $20 \times$ TaqMan $^{\circledR}$ gene expression assay (Applied Biosystems) on an ABI Prism 5700 sequence detection system (SDS5700; Applied Biosystems).

Expression levels of the transcript for TATA binding protein $(T b p)$ were used for the normalization of Glol transcript levels. Expression changes were analyzed with the $2^{-\Delta \Delta \mathrm{Ct}}$ method [32]. The following TaqMan ${ }^{\circledR}$ assays were employed: Mm00844954_s1 (Glol) and Mm00446973_m1 (Tbp).

\section{Immunoblots}

Following tissue homogenization with RIPA buffer (50 mM TRIS pH 8.0, $150 \mathrm{mM} \mathrm{NaCl,} \mathrm{1 \%} \mathrm{Triton} \mathrm{X-100,}$ $0.5 \%$ Na-deoxycholate, $0.1 \%$ SDS) supplemented with complete protease inhibitor cocktail (Roche; Penzberg, Germany), samples were incubated at $4^{\circ} \mathrm{C}$, rotating for 20 min. Brain tissue homogenates were centrifuged for $15 \mathrm{~min}$ at $4,500 \times \mathrm{g}$ and $4^{\circ} \mathrm{C}$ and supernatants collected. Then $20 \mu \mathrm{g}$ of protein were separated in $10 \%$ tris-glycine polyacrylamide and transferred onto a PVDF membrane (Bio-Rad; Hercules, CA, USA). Membranes were blocked with $5 \%$ fat-free milk in phosphate buffered saline (PBS)/ $0.1 \%$ Tween ( $\mathrm{T}$ ) for $1 \mathrm{~h}$ at room temperature (RT) and incubated with the primary antibody overnight at $4{ }^{\circ} \mathrm{C}$ (antiGLO1 (T-16), 1:200 dilution, Santa Cruz Biotechnology (Santa Cruz, CA, USA), \#sc-50732 or anti-beta-actin, 1:10,000 dilution, Sigma-Aldrich (Hamburg, Germany), \#A-5441 for normalization) in PBS/T, washed three times with PBS/T and incubated with the secondary antibody (horseradish peroxidase conjugated anti-goat IgG, 1:30,000 dilution, Santa Cruz Biotechnology, \#sc-2020 or horseradish peroxidase-linked anti-mouse 1:15,000 dilution, Amersham Biosciences, \#NA931V) for $1 \mathrm{~h}$ at RT. After washing, the secondary antibody was detected with a chemiluminescent substrate (SuperSignal West Pico 
Chemiluminescent; Thermo Fisher Scientific; Rockford, IL, USA). Densitometric analyses utilized TotalLab software (Amersham Biosciences).

\section{Assay of glyoxalase 1 activity}

Flash-frozen mouse brain tissue (50-100 mg wet weight) was homogenized in $400 \mu \mathrm{l} 10 \mathrm{mM}$ sodium phosphate buffer, $\mathrm{pH} 7.4$ and $4^{\circ} \mathrm{C}$, and centrifuged $(20,000 \times g$, $30 \mathrm{~min}, 4^{\circ} \mathrm{C}$ ). The supernatant was used as the cytosolic extract for determination of GLO1 activity and protein content (Bradford method). The activity of GLO1 is determined by measuring the initial rate of formation of $S$-D-lactoylglutathione from the hemithioacetal formed nonenzymatically from MG and reduced glutathione. This was conveniently determined by following the increase in absorbance at $240 \mathrm{~nm}$ for which $\Delta \varepsilon_{240}=2.86 \mathrm{mM}^{-1} \mathrm{~cm}^{-1}$ [33]. Hemithioacetal was prepared by pre-incubation of methylglyoxal $(2 \mu \mathrm{mol})$ with glutathione $(2 \mu \mathrm{mol})$ at $37^{\circ} \mathrm{C}$ for $10 \mathrm{~min}$ in sodium phosphate buffer $(50 \mathrm{mM}, \mathrm{pH} 6.6$, $998 \mu \mathrm{l})$. The tissue extract $(2 \mu \mathrm{l})$ was added and the absorbance at $240 \mathrm{~nm}$ monitored with time for $5 \mathrm{~min}$. The activity of GLO1 is deduced from the initial increase in absorbance, corrected for homogenization buffer blank. GLO1 activity is given in units per mg protein where one unit of GLO1 activity is the amount of enzyme which catalyzes the formation of $1 \mu \mathrm{mol}$ of $S$-D-lactoylglutathione per minute under assay conditions.

Measurement of dicarbonyls in brain tissue

Dicarbonyl metabolites glyoxal, methylglyoxal (MG) and 3-deoxyglucosone (3-DG) were determined by derivatization with 1,2-diaminobenzene and quantitation of the resulting quinoxaline adducts by stable isotopic dilution analysis liquid chromatography-tandem mass spectrometry (LC-MS/MS). Brainstem/midbrain and cerebral cortex (10-20 mg wet weight) of 18-month-old KO and WT mice were homogenized in $10 \%$ ice-cold trichloroacetic acid (TCA); $25 \mu \mathrm{l}$. Stable isotopic standards $\left(\left[{ }^{13} \mathrm{C}_{2}\right]\right.$ glyoxal, $\left[{ }^{13} \mathrm{C}_{3}\right]$ methylglyoxal and $\left[{ }^{13} \mathrm{C}_{6}\right] 3-\mathrm{DG} ; 2 \mathrm{pmol}$ ) were added to the samples, mixed, and then centrifuged $\left(20,000 \times g, 30 \mathrm{~min}, 4^{\circ} \mathrm{C}\right)$. The supernatant $(35 \mu \mathrm{l})$ was removed, sodium azide $(6 \%, 5 \mu \mathrm{l})$ added, and then finally $10 \mu \mathrm{l} \quad 0.5 \mathrm{mM}$ 1,2-diaminobenzene solution containing $0.5 \mathrm{mM}$ diethylenetriamine penta-acetic acid (DETAPAC) and $0.2 \mathrm{M} \mathrm{HCl}$ were added. The samples were incubated in the dark for $4 \mathrm{~h}$. Calibration standards were prepared and derivatized concurrently containing 2 pmol isotopic standards and 0-10 pmol glyoxal, methylglyoxal and 3-deoxyglucosone.

Samples were analyzed by LC-MS/MS with a Waters Acquity ultrahigh pressure liquid chromatography (UPLC) system linked to a Waters Quattro Premier XE tandem mass spectrometer. The column was a BEH C18 $1.7-\mu \mathrm{m}$ particle size, $2.1 \times 100 \mathrm{~mm}$ with a guard column $(5 \times 2.1 \mathrm{~mm})$. The mobile phase was $0.1 \%$ trifluoroacetic acid in water with a linear gradient of 0 to $50 \%$ acetonitrile over $10 \mathrm{~min}$; the flow rate was $0.2 \mathrm{ml} / \mathrm{min}$. For mass spectrometric detection, the capillary voltage was $0.6 \mathrm{kV}$, the ion source temperature $120^{\circ} \mathrm{C}$, the desolvation gas temperature $350^{\circ} \mathrm{C}$, and cone and desolvation gas flows 140 and $900 \mathrm{l} / \mathrm{h}$, respectively. The retention time $\left(R_{\mathrm{t}}\right)$, mass transitions (molecular ion $>$ fragmentation) for analyte and internal standard, collision energy (CE), cone voltage (CV), limit of detection (LOD), and analytical recovery (\%) for derivatized analytes, 3-DG, glyoxal and methylglyoxal and were, respectively: $R_{\mathrm{t}}=5.8,7.3$ and 7.9 min; mass transitions for analyte $235.2>199.0,131.0>77.1$ and $145.0>77.1 \mathrm{Da}$ and internal standards $241.2>205.0$, $133.0>77.1$ and $148.0>77.1 \mathrm{Da} ; \mathrm{CE}=16,28$ and $28 \mathrm{eV} ; \mathrm{CV}=21,24$ and $24 \mathrm{~V} ; \mathrm{LOD}=34,32$ and $8 \mathrm{fmol}$; and analytical recovery 76,99 , and $94 \%$.

Determination of protein glycation, oxidation, and nitration adducts

Protein glycation, oxidation, and nitration adduct residues of protein extracts from brainstem/midbrain as well as cortex were determined by stable isotopic dilution analysis liquid chromatography with tandem mass spectrometric detection (LC-MS/MS) after exhaustive enzymatic hydrolysis [34].

Analytes determined were: early glycation adduct $\mathrm{N} \varepsilon$-fructosyl-lysine (FL); advanced glycation endproducts (AGEs)—Ne-carboxymethyl-lysine (CML), Ne-carboxyethyl-lysine (CEL), hydroimidazolones derived from glyoxal, methylglyoxal and 3-deoxyglucosone (G-H1, MG$\mathrm{H} 1$ and 3DG-H, respectively), pentosidine, $\mathrm{N} \omega$-carboxymethyl-arginine (CMA), $S$-carboxymethyl-cysteine (CMC) and MG-derived lysine dimer (MOLD); oxidation adductsmethionine sulfoxide (MetSO), dityrosine (DT) and $\mathrm{N}$-formylkynurenine (NFK); the nitration adduct 3-nitrotyrosine (3-NT); and related amino acids-lysine (lys), arginine (arg), methionine (met), tyrosine (tyr), and tryptophan (trp).

Protein extracts prepared for GLO1 activity measurement $(0.2-5 \mathrm{mg}$ protein) were washed by four cycles of dilution to $500 \mu \mathrm{l}$ and concentration to $50 \mu \mathrm{l}$ in water over a $10-\mathrm{kDa}$ cut-off microspin filter and $100 \mu \mathrm{g}$ of protein were hydrolyzed exhaustively by sequential addition of pepsin, pronase $\mathrm{E}$, and aminopeptidase with prolidase as described [35]. Analytes were detected by electrospraypositive ionization multiple-reaction monitoring LC-MS/ MS and quantified by stable isotopic dilution analysis as described with minor modifications [36]. 
Pentosidine was determined by concurrent fluorescence detection and quantified by reference to a calibration curve response of authentic standard. LC-MS/MS and fluorescence detection was performed with a Waters Acquity UPLC system with Acquity fluorescence detector and Quattro Premier XE tandem mass spectrometer.

\section{Open field test}

Spontaneous motor activity was recorded over a period of 5 min using the parameters constituting the BBB score [37] by measuring horizontal and vertical interruption of infrared beams in a $20 \times 20 \mathrm{~cm}$ open field arena of the DigiScan activity monitor (Omnitech Electronics; Columbus, $\mathrm{OH}$, USA).

\section{Statistical analysis}

Statistical analyses of the data derived from qPCRs, immunoblots, enzyme activity assays, mass spectrometry measurements of AGEs/oxidative markers, and open field behavior assessments were performed via Prism 3 software (GraphPad Software; La Jolla, CA, USA) using unpaired two-tailed $t$ tests. Data are presented as mean \pm SEM. In the figures, significant differences were illustrated with asterisks $(* p<0.05 ; * * p<0.01 ; * * * p<0.001)$.

\section{Results}

Brain transcriptome profile reveals strong upregulation of Glol

A genome-wide transcriptome analysis in striatum and cerebellum of $\mathrm{KO}$ and age-/sex-matched WT mice was performed to gain hypothesis-free insight into the physiological function of the presynaptic protein alpha-synuclein. For optimal signal-noise separation in light of the small expression changes to be expected in complex brain tissue, we maximized consistency criteria by employing 26 Affymetrix oligonucleotide microarray chips to compare $13 \mathrm{KO}$ versus $13 \mathrm{WT}$ brain tissue extracts. To represent brain tissue known to be involved in $\mathrm{PD}$, we chose the striatum. To represent brain regions known for maximal resistance to PD in spite of high alpha-synuclein expression, we chose cerebellar tissue. Given the importance of age for synaptic plasticity and learning as well as for PD, young adult animals at the age of 6 months and old animals at the age of 21 months were employed.

Overall, we found the gene expression pattern to be very similar for both genotypes, with only a few specific transcripts showing dysregulation both in striatum and cerebellum of young as well as old KO animals. Six genes showing decreased expression were reported in a separate manuscript [38]. This paper is focused on upregulated transcripts, reporting for the first time six other non-anonymous coding sequences exhibiting consistently increased expression (Table 1; in alphabetical order): gamma-aminobutyric acid (GABA-A) receptor subunit gamma 2 (Gabrg2; up to 1.47-fold), glyoxalase I (Glo1, up to 2.26fold), ISY1 splicing factor homolog (S. cerevisiae) (Isyl, up to 1.88 -fold), potassium channel modulatory factor 1 (Kcmfl, up to 1.6-fold), polymerase (DNA-directed) epsilon 4 subunit p12 (Pole4, up to 4.16-fold) and cytotoxic granule-associated RNA binding protein 1 (Tial; up to 14.98-fold). Interestingly, we observed a significant upregulation of Gabrg2 upon analysis of the oligonucleotide 1418177_at, but a significant downregulation of Gabrg2 upon analysis of oligonucleotide 1437147_at [38]. A systematic database inquiry showed that the two oligonucleotide spots onto the Affymetrix microarray represent different isoforms of Gabrg2: Affymetrix spot \#1418177_at does not distinguish the Gabrg2 isoforms 1 and 2, while Affymetrix spot \#1437147_at represents only the short isoform 2 .

The increases of Glol as well as Pole4 transcripts were the only upregulations detected consistently by several different oligonucleotide spots (Table 1). These two transcripts may reflect glucose stress and DNA damage occurring in response to alpha-synuclein deficiency. Further validation studies were focused on glyoxalase I in view of its consistency and the availability of tools for functional studies.

Independent qPCR analyses confirm significant increases for Glol

To extend the transcriptome survey with an independent technique in further brain regions and ages, qPCR analyses (Table 2) were performed using RNA extracts from additional animals. The elevation of Glol transcript levels at age 19 months was also detected in striatum with a factor of 2.72 $( \pm 0.33)$-fold $(n=5 /$ genotype; $p=0.0013)$. At the younger age of 6 months in cerebellum, brainstem, midbrain and cortex, increases of $1.83( \pm 0.13)$-fold $(n=4 / \mathrm{KO}$ and $n=3 / \mathrm{WT} ; p=0.0153), 1.95$ ( \pm 0.04$)$-fold $(n=4 /$ genotype; $p=0.0008), 1.74$ ( \pm 0.07$)$-fold $(n=4 /$ genotype; $p=0.0033)$ and $1.60 \quad( \pm 0.08)$-fold $(n=5 /$ genotype; $p=0.0090)$ were documented, respectively. At postnatal day 7 (pnd7) in complete brain hemispheres, an increase by 2.17 ( \pm 0.10$)$-fold $(n=4 /$ genotype; $p<0.0001)$ was detected. Thus, the data indicate an early, ubiquitous, and constant upregulation of Glol transcript levels throughout the brain, without tissue specificity or temporal dynamics. 
Table 1 Global transcriptome analysis in the brain of SNCA-deficient mice

\begin{tabular}{|c|c|c|c|c|c|c|c|c|}
\hline \multirow[t]{3}{*}{$\begin{array}{l}\text { Affymetrix } \\
\text { spot ID }\end{array}$} & \multirow[t]{3}{*}{$\begin{array}{l}\text { Gene } \\
\text { symbol }\end{array}$} & \multirow[t]{3}{*}{ Gene name } & \multicolumn{4}{|c|}{$\begin{array}{l}\text { Fold expression change } \\
\text { (KO versus WT) }\end{array}$} & \multirow[t]{3}{*}{ Gene function } & \multirow[t]{3}{*}{ References } \\
\hline & & & \multicolumn{2}{|c|}{ Cerebellum } & \multicolumn{2}{|c|}{ Striatum } & & \\
\hline & & & Young & Old & Young & Old & & \\
\hline 1418177_at & Gabrg2 & $\begin{array}{l}\text { Gamma-aminobutyric acid } \\
\text { (GABA-A) receptor, subunit } \\
\text { gamma } 2\end{array}$ & 1.42 & 1.47 & 1.30 & 1.27 & $\begin{array}{l}\text { Synaptic transmission; } \\
\text { GABA signaling pathway }\end{array}$ & {$[63]$} \\
\hline 1451240_a_at & Glo1 & Glyoxalase 1 & 2.06 & 2.14 & 2.09 & 1.83 & Carbohydrate metabolism; & {$[36,43,64]$} \\
\hline 1424108_at & Glo1 & & 2.10 & 2.26 & 1.95 & 1.81 & $\begin{array}{r}\text { Detoxification of } \\
\text { methylglyoxal }\end{array}$ & \\
\hline 1436070_at & Glo1 & & 1.62 & 1.64 & 1.53 & 1.50 & & \\
\hline 1424109_a_at & Glo1 & & 1.95 & 2.11 & 1.88 & 1.68 & & \\
\hline 1459728_at & Isyl & $\begin{array}{l}\text { ISY1 splicing factor homolog } \\
\quad(\text { S. cerevisiae })\end{array}$ & 1.57 & 1.61 & 1.88 & 1.71 & mRNA processing & {$[65]$} \\
\hline 1418694_at & Kcmfl & $\begin{array}{l}\text { Potassium channel modulatory } \\
\text { factor } 1\end{array}$ & 1.53 & 1.51 & 1.45 & 1.60 & Protein ubiquitination & {$[66]$} \\
\hline 1444739_at & Pole4 & $\begin{array}{l}\text { Polymerase (DNA-directed) } \\
\text { epsilon 4, p12 subunit }\end{array}$ & 4.16 & 2.58 & 3.85 & 3.08 & DNA replication; & {$[67,68]$} \\
\hline 1423371_at & Pole4 & & 1.57 & 1.51 & 1.31 & 1.28 & DNA repair & \\
\hline 1431708_a_at & Tial & $\begin{array}{l}\text { Cytotoxic granule-associated } \\
\text { RNA binding protein } 1\end{array}$ & 13.54 & 8.07 & 14.98 & 12.41 & $\begin{array}{l}\text { Induction of apoptosis; } \\
\text { mRNA processing }\end{array}$ & {$[69,70]$} \\
\hline
\end{tabular}

Identification of six genes with consistently increased transcript levels in two regions at two ages

Table 2 qPCR analysis shows Glo1 transcript levels to be ubiquitously and persistently increased in alpha-synuclein-deficient mouse brain

\begin{tabular}{lllr}
\hline Brain region & Age & Fold expression change (KO versus WT) & $p$ value \\
\hline Striatum & 19 months & $+2.73( \pm 0.33)$ & $0.0013^{* *}$ \\
Brainstem & 6 months & $+1.95( \pm 0.04)$ & $0.0008^{* * *}$ \\
Midbrain & 6 months & $+1.74( \pm 0.07)$ & $0.0033^{* *}$ \\
Cortex & 6 months & $+1.60( \pm 0.08)$ & $0.0090^{* *}$ \\
Cerebellum & 6 months & $+1.83( \pm 0.13)$ & $0.0153^{*}$ \\
Left brain hemisphere & 7 days & $+2.17( \pm 0.10)$ & $<0.0001^{* * *}$ \\
\hline
\end{tabular}

Expression levels of the transcript for TATA binding protein $(\mathrm{Tbp})$ were used for normalization of Glol transcript levels. Fold expression changes are presented as mean \pm SEM and significant differences were highlighted with asterisks $(* p<0.05, * * p<0.01$, and $* * * p<0.001$; $t$ test). $n=3-5$ animals/genotype

Immunoblot analysis confirms strong increases for GLO1 protein in brain

To investigate whether the elevated Glol transcript levels are translated to GLO1 protein levels, we performed immunoblot analysis (Fig. 1) employing protein extracts from striatum of additional $\mathrm{KO}$ and WT mice at age 19 months. Concordant with our previous investigations on transcript level via microarray and qPCR, a significant and strong increase of GLO1 protein levels by 3.26 ( \pm 0.32$)$-fold $(n=5 /$ genotype; $p=0.0003)$ was observed.
GLO1 enzyme activity and dicarbonyl contents

To validate the biological role of increased GLO1 expression, enzymatic activity of GLO1 was assessed in brainstem/midbrain and cortex of old WT and KO mice. GLO1 activity was increased $49 \%$ in the brainstem $/ \mathrm{mid}$ brain of $\mathrm{KO}$ mice with respect to WT controls (Fig. 2a; $p<0.05)$ and $94 \%$ in cortex of $\mathrm{KO}$ mice with respect to WT controls (Fig. 2b; $p<0.001$ ). The concentration of the GLO1 substrate glyoxal (Fig. 2c, d) was similar in brainstem/midbrain and cortex of $\mathrm{KO}$ versus WT mice $(1.25 \pm 0.16$ vs. $1.32 \pm 0.27 \mathrm{nmol} / \mathrm{g}$ wet weight $)$ whereas 


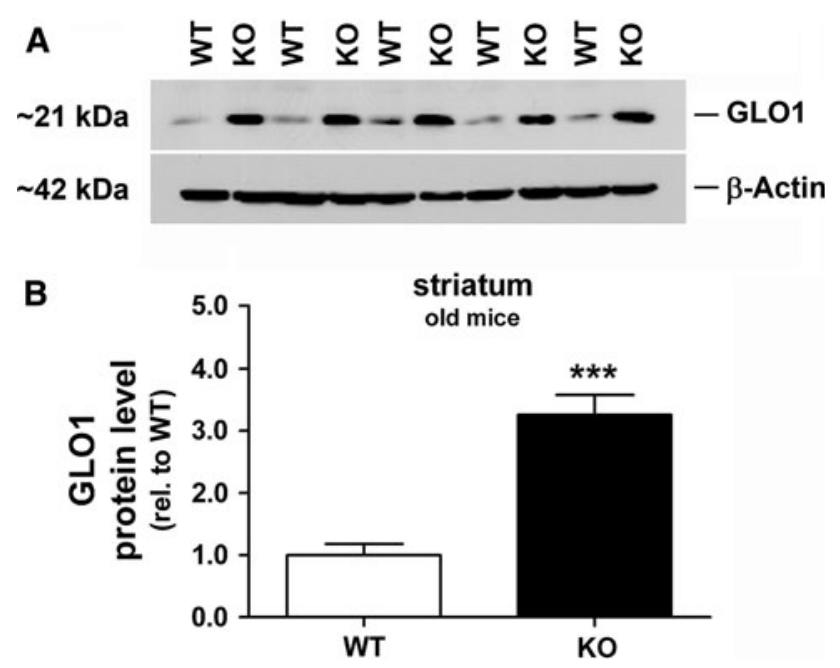

Fig. 1 Elevation of GLO1 protein levels in striatum of alphasynuclein-deficient mice. a Immunoblot analysis revealed $\mathbf{b}$ significant elevated GLO1 protein levels (3.26 \pm 0.32 -fold; $n=5 /$ genotype, $p=0.0003)$ in the striatum of KO mice at old age (19 months) in comparison with corresponding WT controls. Protein expression levels of beta-actin were used for normalization of GLO1 protein levels and to confirm equal protein loading. Data are presented as mean $\pm \mathrm{SD}$ and significant differences were highlighted with asterisks (*** $p<0.001 ; t$ test). $n=5$ animals/genotype

the concentration of methylglyoxal (MG; Fig. 2e, f) was significantly elevated in both regions (27\% in brainstem/ midbrain and 34\% in cortex; $p<0.05$ ), and higher in the brainstem/midbrain than in cortex of WT mice $(1.47 \pm$ 0.16 vs. $0.30 \pm 0.06 \mathrm{nmol} / \mathrm{g}$ wet weight; $p<0.001)$. The concentrations of the non-GLO1 dicarbonyl 3-deoxyglucosone (3-DG; Fig. 2g, h) were unchanged in $\mathrm{KO}$ mice, being lower in the cortex $(0.11 \pm 0.03 \mathrm{nmol} / \mathrm{g}$ wet weight $)$ than in the brainstem/midbrain of WT mice $(0.19 \pm$ $0.06 \mathrm{nmol} / \mathrm{g}$ wet weight; $p<0.05)$. Thus, both GLO1 activity and MG levels were significantly elevated in both brain regions of old $\mathrm{KO}$ mice.

\section{GLO1 effects on spontaneous locomotor behavior}

GLO1 upregulation was previously found to influence behavior in mice. Investigations into biomarkers of anxiety traits observed increased expression levels of GLO1 in brains of mouse strains particularly susceptible to anxiety, and showed that lentiviral transduction of GLO1 in the cingulate cortex induced the mice to spend $16 \%$ more time close to the wall of an open field chamber [39]. Therefore, we used the open field paradigm to determine whether similar anxiety-related changes of movement were detectable in SNCA-deficient mice. Indeed, the documentation of spontaneous motor activity over a 5-min period in old animals demonstrated a $28 \%$ significantly reduced willingness to leave the area close to the walls and roam in the unprotected center of the open field chamber (Fig. 3). Thus, GLO1 upregulation in SNCA-deficient mice modulated animal behavior in a previously reported manner.

Glucose stress marker FL is elevated in both brain regions, three MG-dependent proteome modifications are increased in brainstem/midbrain in spite of GLO1 upregulation

Analysis of protein damage by glycation, oxidation, and nitration in WT and KO mice showed increased early glycation of brainstem/midbrain and cortex proteins. Fructosyl-lysine (FL) residue content was increased 92 and $78 \%$ in brainstem/midbrain and cortex, respectively, of KO mice with respect to WT controls (Table 3), suggesting elevated glucose stress throughout the brain. With regard to GLO1-dependent AGEs formation, there was a small increase in CML residue content (15\%) and greater increases in CMC residue (157\%) and CEL residue (32\%) contents in the brainstem/midbrain of $\mathrm{KO}$ versus WT mice, suggesting AGE-formation to exhibit tissue-specificity due to additional factors. For oxidative markers, there was only a minor decrease of dityrosine (DT) residue content of brainstem/midbrain protein in KO mice with respect to WT controls $(-26 \%)$, indicating the glycation stress to be insufficient to elicit major pathological effects. For protein nitration, 3-nitrotyrosine (3-NT) residues were quantitatively low but increased $115 \%$ in brainstem/midbrain of KO versus WT mice (Table 3). Thus, tissue-specific factors in the brainstem/midbrain appear to mediate a specific increase of GLO1-dependent AGE formation and protein nitration in spite of apparently ubiquitous glucose toxicity, MG and GLO1 induction.

\section{Discussion}

We undertook a hypothesis-free approach to elucidate the physiological roles of the presynaptic protein alpha-synuclein. We found SNCA ablation to have a prominent effect within the mouse brain transcriptome on GLO1 induction and to enhance markers of protein glycation. GLO1 is an enzyme with ubiquitous expression in all cell types and cytosolic location, which is conserved with 50\% amino acid identity from microorganisms and plants to mammals [40]. Interacting with the cofactor glutathione, GLO1 is important for the detoxification of the dicarbonyl compounds glyoxal and methylglyoxal which are formed by the degradation of triosephosphates mainly during glycolysis, but also during lipid peroxidation and other cellular processes. GLO1 transcript levels are induced by its substrates, as was shown by administering glyoxal to the drinking water of rats or MG into the cerebrospinal fluid of 
Fig. 2 Elevated GLO1 activity and dicarbonyl stress in alphasynuclein-deficient mouse brain. Brainstem/midbrain and cortex from old WT and KO mice were analyzed for GLO1 enzymatic activity (a, b) and dicarbonyl stress markers glyoxal $(\mathbf{c}, \mathbf{d})$, methylglyoxal $(\mathbf{e}, \mathbf{f})$ and the non-GLO1 dependent dicarbonyl 3-DG (g, h). Data are presented as mean \pm SD and significant differences were highlighted with asterisks $(* p<0.05$ and $* * * p<0.001$; $t$ test). $n=6$ animals/genotype
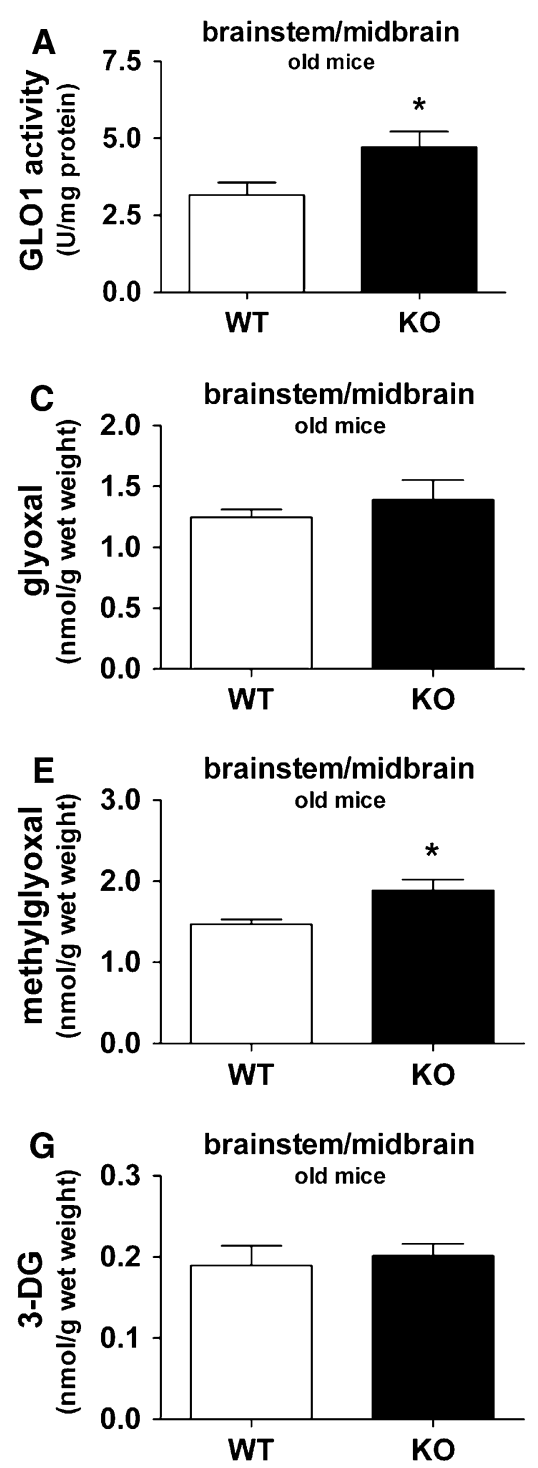
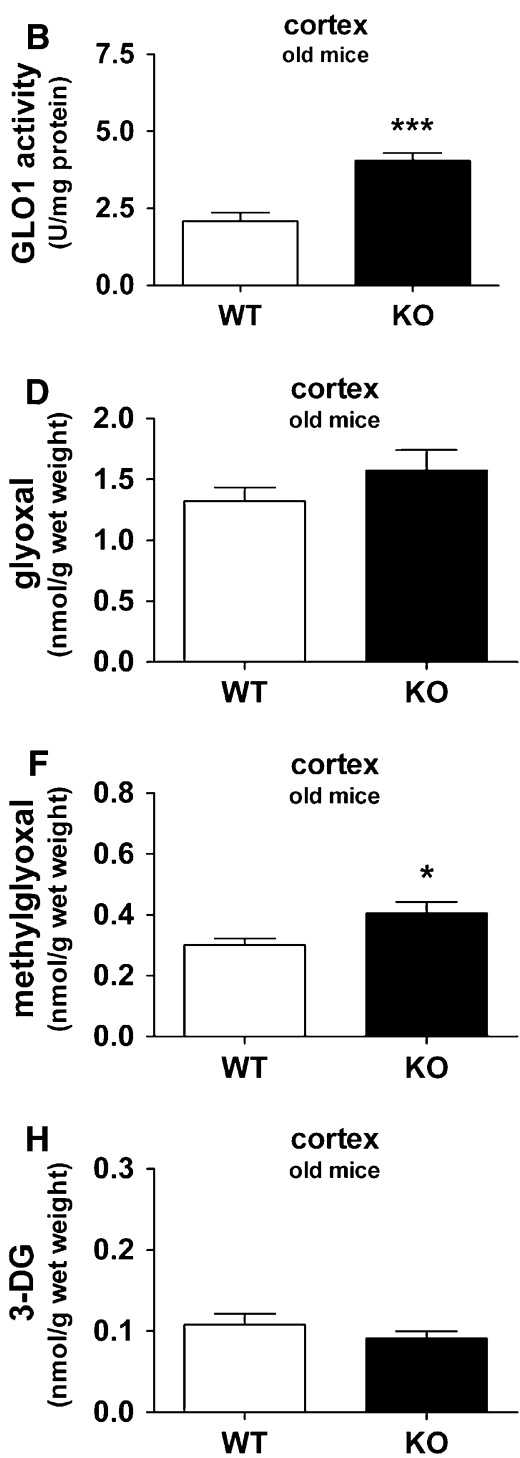

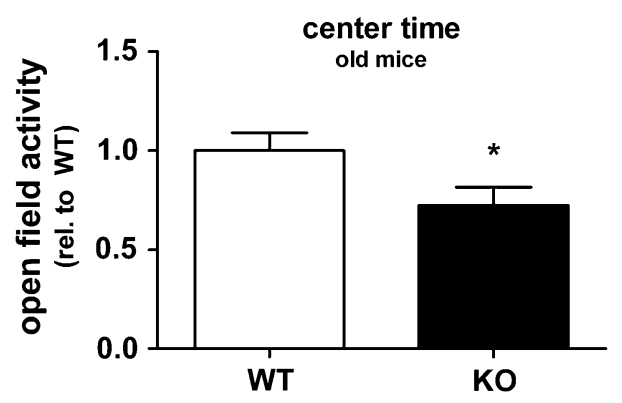

Fig. 3 Reduced exploratory motor activity in alpha-synucleindeficient mice. Automatic recording of the spontaneous movement of untrained old mice over $5 \mathrm{~min}$ by infrared beams and calculating the time spent within the $5 \times 5 \mathrm{~cm}$ chamber center versus the margins showed a significant preference of KO animals to spend time in the "protected" environment close to the walls ( $n=22$ WT vs. $n=28 \mathrm{KO})$. Data are presented as mean $\pm \mathrm{SD}$ and significant differences were highlighted with asterisks ( ${ }^{*} p<0.05 ; t$ test) mice $[41,42]$. Thus, GLO1 protects cells against dicarbonyl damage to proteins and nucleotides [43], having a significant role in countering proteome damage in hyperglycemia and aging [44, 45]. Under glucose stress conditions, hexoses react mainly with lysine side chain amino groups of proteins to form the early glycation adduct FL, whereas the later glycation of proteins by the triose metabolites glyoxal and methylglyoxal is directed mainly to arginine residues with minor modification of lysine and cysteine residues, forming AGEs with signaling function or with toxic effects if in excess. In view of its protective role against glucose toxicity, GLO1 has been extensively studied in diabetes mellitus models [45].

In SNCA-deficient brain tissue, the upregulation of GLO1 expression occurs with regard to transcript levels, protein levels and enzymatic activity consistently in all 
Table 3 Markers of protein damage in brainstem/midbrain and cortex of old alpha-synuclein-deficient and wild-type mice

\begin{tabular}{|c|c|c|c|c|c|}
\hline \multirow[t]{2}{*}{ Type of modification } & \multirow[t]{2}{*}{ Analyte } & \multicolumn{2}{|l|}{ Brainstem/midbrain } & \multicolumn{2}{|l|}{ Cortex } \\
\hline & & WT & $\mathrm{KO}$ & WT & $\mathrm{KO}$ \\
\hline Fructosamine & FL & $8.57 \pm 3.55$ & $16.48 \pm 5.39^{*}$ & $9.2 \pm 3.1$ & $16.4 \pm 2.8 * *$ \\
\hline \multirow[t]{9}{*}{ AGE } & CML & $0.101 \pm 0.008$ & $0.116 \pm 0.014^{*}$ & $0.144 \pm 0.043$ & $0.132 \pm 0.019$ \\
\hline & CMA & $0.156 \pm 0.034$ & $0.155 \pm 0.038$ & $0.124 \pm 0.049$ & $0.129 \pm 0.031$ \\
\hline & $\mathrm{CMC}$ & $0.134 \pm 0.035$ & $0.345 \pm 0.174 *$ & $0.398 \pm 0.127$ & $0.428 \pm 0.075$ \\
\hline & CEL & $0.067 \pm 0.012$ & $0.097 \pm 0.022 *$ & $0.061 \pm 0.018$ & $0.076 \pm 0.018$ \\
\hline & MOLD & $0.030 \pm 0.016$ & $0.057 \pm 0.028$ & $0.161 \pm 0.084$ & $0.195 \pm 0.079$ \\
\hline & G-H1 & $0.089 \pm 0.060$ & $0.112 \pm 0.087$ & $0.075 \pm 0.040$ & $0.075 \pm 0.036$ \\
\hline & MG-H1 & $0.765 \pm 0.166$ & $0.772 \pm 0.117$ & $0.382 \pm 0.077$ & $0.418 \pm 0.096$ \\
\hline & 3DG-H & $0.247 \pm 0.040$ & $0.299 \pm 0.059$ & $0.325 \pm 0.087$ & $0.253 \pm 0.032$ \\
\hline & Pentosidine & $0.0032 \pm 0.0003$ & $0.0036 \pm 0.0008$ & $0.0032 \pm 0.0019$ & $0.0034 \pm 0.0005$ \\
\hline \multirow[t]{3}{*}{ Oxidation } & MetSO & $17.7 \pm 3.2$ & $15.1 \pm 1.3$ & $15.5 \pm 2.2$ & $14.6 \pm 1.3$ \\
\hline & DT & $0.018 \pm 0.001$ & $0.013 \pm 0.005^{*}$ & $0.011 \pm 0.001$ & $0.012 \pm 0.002$ \\
\hline & NFK & $0.506 \pm 0.137$ & $0.629 \pm 0.104$ & $0.350 \pm 0.059$ & $0.448 \pm 0.145$ \\
\hline Nitration & 3-NT & $0.0028 \pm 0.0006$ & $0.0059 \pm 0.0015^{* * *}$ & $0.0036 \pm 0.0004$ & $0.0046 \pm 0.0022$ \\
\hline
\end{tabular}

Data for FL, CML, CEL, CMC, MOLD, and PENT are mmol/mol lys, for G-H1, MG-H1, 3DG-H and CMA are mmol/mol arg, for MetSO are $\mathrm{mmol} / \mathrm{mol} \mathrm{met,} \mathrm{for} \mathrm{DT} \mathrm{and} \mathrm{3-NT} \mathrm{are} \mathrm{mmol} / \mathrm{mol}$ tyr and for NFK, mmol/mol trp. Data are presented as mean \pm SD and significant differences were highlighted with asterisks (* $p<0.05$ and $* * * p<0.001 ; t$ test). $n=6$ animals/genotype

regions and at all ages documented. This was linked to a ubiquitous increase in MG concentration. The relative flux of MG formation is expected to be proportional to the product of GLO1 activity x steady-state MG concentration. On this basis, the flux of MG has likely increased $\sim$ twofold in the brainstem/midbrain and $\sim$ threefold in the cortex of KO with respect to WT mice. Furthermore, the GLO1 induction was accompanied by a deficit in exploratory movement activity, as observed previously in anxiety-biomarker studies in rodents. These data are consistent at genetic, biochemical, and behavioral levels and indicate that the transcriptional upregulation of GLO1 responds to increased formation of MG in the brain with subsequent changes in neural function and behavior.

The glucose-derived early glycation adduct FL content of protein was also increased ubiquitously in $\mathrm{KO}$ mouse brain. This might be caused by increased neuronal glucose concentration, impaired protein turnover or decreased repair of FL residues by fructosamine 3-phosphokinase. The brain is high in expression of this enzyme and hence low in FL residue content [46, 47]. KO mice might have impaired repair of FL residues. Alternatively, a ubiquitous elevation of brain glucose levels and glycolytic activity would explain the increased FL levels and would also explain the GLO1 upregulation through substrate induction. The loss-of-function of alpha-synuclein may produce increased glucose entry and utilization. Although alphasynuclein was not previously implicated in glucose metabolism, this interpretation of the GLO1 upregulation is supported by the previously published transcriptional downregulation of Rmnd5a in SNCA-KO brain tissue [38]. Its well-studied yeast ortholog Rmd5 is known to negatively regulate gluconeogenesis through an ubiquitination of fructose-1,6-bisphosphatase (FBPase). The notion of elevated glucose flux is compatible with previous observations that SNCA deficiency confers resistance to inhibitors of respiration [48-52], since increased ATP-generation through glycolysis would decrease cellular dependence on mitochondrial respiration and might diminish the ROS burden while enhancing AGE formation. Thus, a role of alpha-synuclein for glucose utilization in brain tissue would provide a credible explanation for our findings.

The increased AGEs in KO mouse brains were those formed by GLO1 substrates (CMC and CML formed from glyoxal and CEL formed from methylglyoxal; CML is also formed by oxidative degradation of FL residues). This elevation occurred as a consequence of increased MG concentration in spite of increased GLO1 activity, suggesting that $\mathrm{KO}$ mice have enhanced flux of formation of glyoxal and methylglyoxal. Thus, the upregulation of GLO1 activity provides an imperfect protection of the proteome against the dicarbonyl stress. Surprisingly, there was no increase in oxidative damage in the $\mathrm{KO}$ mice as indicated by lack of increase in methionine sulfoxide (MetSO), DT and $\mathrm{N}$-formylkynurenine (NFK) residues. This lack of oxidative stress is in keeping with the lack of neurodegeneration and the normal lifespan of SNCA-KO mice. There was, however, increased 3-NT in brainstem/midbrain sections suggesting there is increased protein nitration damage in this region. In the absence of oxidative stress, 3-NT may be 
formed e.g., by inflammation induced expression of iNOS. Nitrosative stress contributes to pathology in neurodegenerative diseases via 3-NT- mediated nitration of proteins and lipids [53]. Interestingly, the significant elevation of AGEs and of 3-NT both were observed specifically in the brainstem/midbrain in spite of the ubiquitous elevation of FL, MG, and GLO1, suggesting additional tissue specific factors to modulate protein damage. In summary, the ubiquitous transcriptional upregulation of GLO1 expression was insufficient in the brainstem/midbrain to prevent glycation damage and nitrosative stress.

Glol transcript upregulation had not been significant in a previous transcriptome profiling effort of SH-SY5Y neuroblastoma cells with SNCA knock-down to about $40 \%$ protein level [54], but the use of DMEM with high glucose supply for mutant and control tumor cells may have precluded this observation. Our findings are clearly important to elucidate the physiological role of alpha-synuclein in brain. Whether they are also relevant for PD pathology remains unclear at present and is beyond the scope of this manuscript. Since the loss-of-function of alpha-synuclein results in GLO1 upregulation in mouse brain, any alphasynuclein gain-of-function in vulnerable areas of PD patient brain might be expected to result in a GLO1 downregulation. Consistent with this notion, a downregulation of GLO1 (also named lactoylglutathione lyase) together with downregulations of four mitochondrial OXPHOS and 3 peroxiredoxins was observed in the midbrain of Parkin-KO mice which model the autosomal recessive PARK2 variant of PD [55]. Thus, alterations of GLO1 expression and possibly glucose flux may occur in parallel to the mitochondrial dysfunction characteristic of PD. Altered GLO1 levels were the only significant expression change upon genome-wide transcriptome profiling in brain tissue from tau mouse mutants modeling Alzheimer's disease [56]. AGEs are capable of inactivating and crosslinking proteins, thus enhancing polymerization e.g., of beta-amyloid [57, 58]. Our findings about a role of alpha-synuclein $\mathrm{KO}$ for protein glycation is therefore consistent with published data that SNCA ablation increases amyloid plaque accumulation and disease progression in transgenic mouse models of $\mathrm{AD}$ without affecting amyloid-beta levels or onset age [59]. Thus, the regulation of GLO1 by alpha-synuclein appears relevant also in the context of neurodegenerative diseases.

At present, it remains unclear whether alpha-synuclein deficiency exerts a direct or indirect regulation of glucose metabolism. It would be interesting now (1) to assess the flux of glucose through anaerobic glycolysis and through the pentose phosphate pathway in these mice, since this might provide a basis to pharmacologically modulate this flux and reduce triosephosphate intermediate burden [60], (2) to study the consequent protein o-glycosylation, since

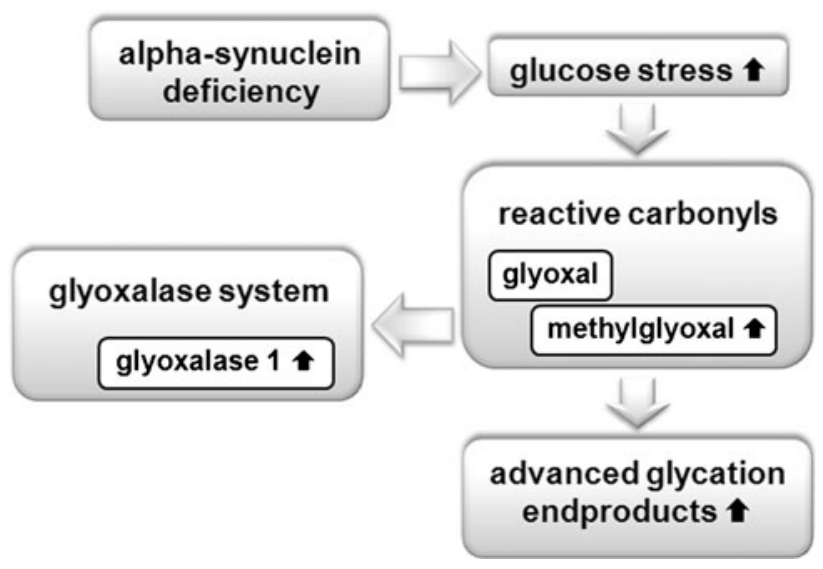

Fig. 4 Summary scheme of glucose toxicity and the documented anomalies in SNCA-KO brain. This schematic depicts the consequences of glucose-induced damage with generation of reactive carbonyls, advanced glycation endproducts and exemplary protein aggregation disorders, a process mitigated by the induction of the cytoprotective glyoxalase system which exerts an anti-AGE effect and modulates the disease risk. Black arrows illustrate the changes observed in SNCA-KO brains

in particular o-GlcNAc formation is known as a key regulator in diabetes mellitus and Alzheimer's disease [61], (3) to determine whether the induction of AGEs affects the levels of RAGE, since this receptor has a key signaling role in inflammation and protein aggregation diseases [62].

In summary, we report ubiquitous glucose-dependent cell stress and brainstem/midbrain-specific glycation and nitrosative stress in spite of a protective induction of GLO1 throughout the brain of SNCA-deficient mice. As illustrated in Fig. 4, we propose that alpha-synuclein modulates brain dicarbonyl metabolism (reflected by the enhanced levels of MG and AGEs and increased GLO1 expression) through an effect on glucose flux.

Acknowledgments The work was supported by the "Deutsche Forschungsgemeinschaft" [DFG grant numbers GI342/1-1, GI342/3-1, AU96/10-1] and the German Ministry of Health in the National Genome Research Network [NGFN2 (01GS0472) and NGFNplus (01GS08138)] and the GerontoMitoSys Network (0315584A). We are indebted to the ZFE Frankfurt for help with the mice and to Birgitt Meseck-Selchow for help with the genotyping.

Conflict of interest None.

Open Access This article is distributed under the terms of the Creative Commons Attribution Noncommercial License which permits any noncommercial use, distribution, and reproduction in any medium, provided the original author(s) and source are credited.

\section{References}

1. Ma QL, Chan P, Yoshii M, Ueda K (2003) Alpha-synuclein aggregation and neurodegenerative diseases. J Alzheimers Dis 5:139-148 
2. Polymeropoulos MH, Lavedan C, Leroy E, Ide SE, Dehejia A, Dutra A, Pike B, Root H, Rubenstein J, Boyer R, Stenroos ES, Chandrasekharappa S, Athanassiadou A, Papapetropoulos T, Johnson WG, Lazzarini AM, Duvoisin RC, Di Iorio G, Golbe LI, Nussbaum RL (1997) Mutation in the alpha-synuclein gene identified in families with Parkinson's disease. Science 276: 2045-2047

3. Singleton AB, Farrer M, Johnson J, Singleton A, Hague S, Kachergus J, Hulihan M, Peuralinna T, Dutra A, Nussbaum R, Lincoln S, Crawley A, Hanson M, Maraganore D, Adler C, Cookson MR, Muenter M, Baptista M, Miller D, Blancato J, Hardy J, Gwinn-Hardy K (2003) Alpha-synuclein locus triplication causes Parkinson's disease. Science 302:841

4. Spillantini MG, Schmidt ML, Lee VM, Trojanowski JQ, Jakes R, Goedert M (1997) Alpha-synuclein in Lewy bodies. Nature 388:839-840

5. Braak H, Del Tredici K, Bratzke H, Hamm-Clement J, SandmannKeil D, Rub U (2002) Staging of the intracerebral inclusion body pathology associated with idiopathic Parkinson's disease (preclinical and clinical stages). J Neurol 249(Suppl 3): III/1-5

6. Jenner P (1993) Altered mitochondrial function, iron metabolism and glutathione levels in Parkinson's disease. Acta Neurol Scand Suppl 146:6-13

7. Bender A, Krishnan KJ, Morris CM, Taylor GA, Reeve AK, Perry RH, Jaros E, Hersheson JS, Betts J, Klopstock T, Taylor RW, Turnbull DM (2006) High levels of mitochondrial DNA deletions in substantia nigra neurons in aging and Parkinson disease. Nat Genet 38:515-517

8. Gandhi S, Wood NW (2005) Molecular pathogenesis of Parkinson's disease. Hum Mol Genet 14:2749-2755

9. Pavese N, Brooks DJ (2009) Imaging neurodegeneration in Parkinson's disease. Biochim Biophys Acta 1792:722-729

10. Kahle PJ, Neumann M, Ozmen L, Haass C (2000) Physiology and pathophysiology of alpha-synuclein. Cell culture and transgenic animal models based on a Parkinson's disease-associated protein. Ann NY Acad Sci 920:33-41

11. Cooper AA, Gitler AD, Cashikar A, Haynes CM, Hill KJ, Bhullar B, Liu K, Xu K, Strathearn KE, Liu F, Cao S, Caldwell KA, Caldwell GA, Marsischky G, Kolodner RD, Labaer J, Rochet JC, Bonini NM, Lindquist S (2006) Alpha-synuclein blocks ERGolgi traffic and Rab1 rescues neuron loss in Parkinson's models. Science 313:324-328

12. Liang J, Clark-Dixon C, Wang S, Flower TR, Williams-Hart T, Zweig R, Robinson LC, Tatchell K, Witt SN (2008) Novel suppressors of alpha-synuclein toxicity identified using yeast. Hum Mol Genet 17:3784-3795

13. van Ham TJ, Thijssen KL, Breitling R, Hofstra RM, Plasterk RH, Nollen EA (2008) C. elegans model identifies genetic modifiers of alpha-synuclein inclusion formation during aging. PLoS Genet 4:e1000027

14. Yeger-Lotem E, Riva L, Su LJ, Gitler AD, Cashikar AG, King OD, Auluck PK, Geddie ML, Valastyan JS, Karger DR, Lindquist S, Fraenkel E (2009) Bridging high-throughput genetic and transcriptional data reveals cellular responses to alpha-synuclein toxicity. Nat Genet 41:316-323

15. Waxman EA, Giasson BI (2009) Molecular mechanisms of alpha-synuclein neurodegeneration. Biochim Biophys Acta 1792: 616-624

16. Chandra S, Gallardo G, Fernandez-Chacon R, Schluter OM, Sudhof TC (2005) Alpha-synuclein cooperates with CSPalpha in preventing neurodegeneration. Cell 123:383-396

17. Thayanidhi N, Helm JR, Nycz DC, Bentley M, Liang Y, Hay JC (2010) Alpha-synuclein delays endoplasmic reticulum (ER)-toGolgi transport in mammalian cells by antagonizing ER/Golgi SNAREs. Mol Biol Cell 21:1850-1863
18. Al-Wandi A, Ninkina N, Millership S, Williamson SJ, Jones PA, Buchman VL (2010) Absence of alpha-synuclein affects dopamine metabolism and synaptic markers in the striatum of aging mice. Neurobiol Aging 31:796-804

19. Cabin DE, Shimazu K, Murphy D, Cole NB, Gottschalk W, McIlwain KL, Orrison B, Chen A, Ellis CE, Paylor R, Lu B, Nussbaum RL (2002) Synaptic vesicle depletion correlates with attenuated synaptic responses to prolonged repetitive stimulation in mice lacking alpha-synuclein. J Neurosci 22:8797-8807

20. Gureviciene I, Gurevicius K, Tanila H (2007) Role of alphasynuclein in synaptic glutamate release. Neurobiol Dis 28:83-89

21. Liu S, Ninan I, Antonova I, Battaglia F, Trinchese F, Narasanna A, Kolodilov N, Dauer W, Hawkins RD, Arancio O (2004) Alpha-synuclein produces a long-lasting increase in neurotransmitter release. EMBO J 23:4506-4516

22. Abeliovich A, Schmitz Y, Farinas I, Choi-Lundberg D, Ho WH, Castillo PE, Shinsky N, Verdugo JM, Armanini M, Ryan A, Hynes M, Phillips H, Sulzer D, Rosenthal A (2000) Mice lacking alpha-synuclein display functional deficits in the nigrostriatal dopamine system. Neuron 25:239-252

23. Senior SL, Ninkina N, Deacon R, Bannerman D, Buchman VL, Cragg SJ, Wade-Martins R (2008) Increased striatal dopamine release and hyperdopaminergic-like behaviour in mice lacking both alpha-synuclein and gamma-synuclein. Eur J Neurosci 27:947-957

24. Chandra S, Fornai F, Kwon HB, Yazdani U, Atasoy D, Liu X, Hammer RE, Battaglia G, German DC, Castillo PE, Sudhof TC (2004) Double-knockout mice for alpha- and beta-synucleins: effect on synaptic functions. Proc Natl Acad Sci USA 101:14966-14971

25. Liu S, Fa M, Ninan I, Trinchese F, Dauer W, Arancio O (2007) Alpha-synuclein involvement in hippocampal synaptic plasticity: role of NO, cGMP, cGK and CaMKII. Eur J Neurosci 25:3583-3596

26. Ellis CE, Murphy EJ, Mitchell DC, Golovko MY, Scaglia F, Barcelo-Coblijn GC, Nussbaum RL (2005) Mitochondrial lipid abnormality and electron transport chain impairment in mice lacking alpha-synuclein. Mol Cell Biol 25:10190-10201

27. Edgar R, Domrachev M, Lash AE (2002) Gene Expression Omnibus: NCBI gene expression and hybridization array data repository. Nucleic Acids Res 30:207-210

28. Gentleman RC, Carey VJ, Bates DM, Bolstad B, Dettling M, Dudoit S, Ellis B, Gautier L, Ge Y, Gentry J, Hornik K, Hothorn $\mathrm{T}$, Huber W, Iacus S, Irizarry R, Leisch F, Li C, Maechler M, Rossini AJ, Sawitzki G, Smith C, Smyth G, Tierney L, Yang JY, Zhang J (2004) Bioconductor: open software development for computational biology and bioinformatics. Genome Biol 5:R80

29. Gautier L, Cope L, Bolstad BM, Irizarry RA (2004) affyanalysis of Affymetrix GeneChip data at the probe level. Bioinformatics 20:307-315

30. Smyth GK (2004) Linear models and empirical bayes methods for assessing differential expression in microarray experiments. Stat Appl Genet Mol Biol 3. (Article3)

31. Smyth GK (2005) Limma: linear models for microarray data. In: Gentleman RC et al (eds) Bioinformatics and computational biology solutions using $\mathrm{R}$ and bioconductor. Springer, Berlin Heidelberg New York, pp 397-420

32. Livak KJ, Schmittgen TD (2001) Analysis of relative gene expression data using real-time quantitative PCR and the 2(-Delta Delta C(T)) Method. Methods 25:402-408

33. Clelland JD, Thornalley PJ (1991) S-2-Hydroxyacylglutathionederivates: enzymatic preparation, purification and characterisation. J Chem Soc Perkin Trans I, 3009-3015

34. Ahmed N, Thornalley PJ, Luthen R, Haussinger D, Sebekova K, Schinzel R, Voelker W, Heidland A (2004) Processing of protein 
glycation, oxidation and nitrosation adducts in the liver and the effect of cirrhosis. J Hepatol 41:913-919

35. Ahmed N, Argirov OK, Minhas HS, Cordeiro CA, Thornalley PJ (2002) Assay of advanced glycation endproducts (AGEs): surveying AGEs by chromatographic assay with derivatization by 6-aminoquinolyl-N-hydroxysuccinimidyl-carbamate and application to Nepsilon-carboxymethyl-lysine- and Nepsilon-(1-carboxyethyl)lysine-modified albumin. Biochem J 364:1-14

36. Thornalley PJ (2003) Glyoxalase I-structure, function and a critical role in the enzymatic defence against glycation. Biochem Soc Trans 31:1343-1348

37. Basso DM, Beattie MS, Bresnahan JC (1995) A sensitive and reliable locomotor rating scale for open field testing in rats. J Neurotrauma 12:1-21

38. Kurz A, Wohr M, Walter M, Bonin M, Auburger G, Gispert S, Schwarting RK (2010) Alpha-synuclein deficiency affects brain Foxp1 expression and ultrasonic vocalization. Neuroscience 166:785-795

39. Hovatta I, Tennant RS, Helton R, Marr RA, Singer O, Redwine JM, Ellison JA, Schadt EE, Verma IM, Lockhart DJ, Barlow C (2005) Glyoxalase 1 and glutathione reductase 1 regulate anxiety in mice. Nature 438:662-666

40. Espartero J, Sanchez-Aguayo I, Pardo JM (1995) Molecular characterization of glyoxalase-I from a higher plant; upregulation by stress. Plant Mol Biol 29:1223-1233

41. Hambsch B, Chen BG, Brenndorfer J, Meyer M, Avrabos C, Maccarrone G, Liu RH, Eder M, Turck CW, Landgraf R (2010) Methylglyoxal-mediated anxiolysis involves increased protein modification and elevated expression of glyoxalase 1 in the brain. J Neurochem 113:1240-1251

42. Ueno $H$, Segawa $T$, Hasegawa $T$, Nakamuro $K$, Maeda $H$, Hiramatsu Y, Okada S, Sayato Y (1991) Subchronic oral toxicity of glyoxal via drinking water in rats. Fundam Appl Toxicol 16:763-772

43. Thornalley PJ (2008) Protein and nucleotide damage by glyoxal and methylglyoxal in physiological systems-role in ageing and disease. Drug Metabol Drug Interact 23:125-150

44. Morcos M, Du X, Pfisterer F, Hutter H, Sayed AA, Thornalley P, Ahmed N, Baynes J, Thorpe S, Kukudov G, Schlotterer A, Bozorgmehr F, El Baki RA, Stern D, Moehrlen F, Ibrahim Y, Oikonomou D, Hamann A, Becker C, Zeier M, Schwenger V, Miftari N, Humpert P, Hammes HP, Buechler M, Bierhaus A, Brownlee M, Nawroth PP (2008) Glyoxalase-1 prevents mitochondrial protein modification and enhances lifespan in Caenorhabditis elegans. Aging Cell 7:260-269

45. Schlotterer A, Kukudov G, Bozorgmehr F, Hutter H, Du X, Oikonomou D, Ibrahim Y, Pfisterer F, Rabbani N, Thornalley P, Sayed A, Fleming T, Humpert P, Schwenger V, Zeier M, Hamann A, Stern D, Brownlee M, Bierhaus A, Nawroth P, Morcos M (2009) C. elegans as model for the study of high glucose-mediated life span reduction. Diabetes 58:2450-2456

46. Delplanque J, Delpierre G, Opperdoes FR, Van Schaftingen E (2004) Tissue distribution and evolution of fructosamine 3-kinase and fructosamine 3-kinase-related protein. J Biol Chem 279: 46606-46613

47. Veiga da-Cunha M, Jacquemin P, Delpierre G, Godfraind C, Theate I, Vertommen D, Clotman F, Lemaigre F, Devuyst O, Van Schaftingen E (2006) Increased protein glycation in fructosamine 3-kinase-deficient mice. Biochem J 399:257-264

48. Dauer W, Kholodilov N, Vila M, Trillat AC, Goodchild R, Larsen KE, Staal R, Tieu K, Schmitz Y, Yuan CA, Rocha M, Jackson-Lewis V, Hersch S, Sulzer D, Przedborski S, Burke R, Hen R (2002) Resistance of alpha-synuclein null mice to the parkinsonian neurotoxin MPTP. Proc Natl Acad Sci USA 99:14524-14529
49. Fountaine TM, Venda LL, Warrick N, Christian HC, Brundin P, Channon KM, Wade-Martins R (2008) The effect of alpha-synuclein knockdown on MPP + toxicity in models of human neurons. Eur J Neurosci 28:2459-2473

50. Klivenyi P, Siwek D, Gardian G, Yang L, Starkov A, Cleren C, Ferrante RJ, Kowall NW, Abeliovich A, Beal MF (2006) Mice lacking alpha-synuclein are resistant to mitochondrial toxins. Neurobiol Dis 21:541-548

51. Robertson DC, Schmidt O, Ninkina N, Jones PA, Sharkey J, Buchman VL (2004) Developmental loss and resistance to MPTP toxicity of dopaminergic neurones in substantia nigra pars compacta of gamma-synuclein, alpha-synuclein and double alpha/ gamma-synuclein null mutant mice. J Neurochem 89:1126-1136

52. Schluter OM, Fornai F, Alessandri MG, Takamori S, Geppert M, Jahn R, Sudhof TC (2003) Role of alpha-synuclein in 1-methyl-4phenyl-1, 2, 3, 6-tetrahydropyridine-induced parkinsonism in mice. Neuroscience 118:985-1002

53. Trostchansky A, Rubbo H (2007) Lipid nitration and formation of lipid-protein adducts: biological insights. Amino Acids 32: 517-522

54. Habig K, Walter M, Stappert H, Riess O, Bonin M (2009) Microarray expression analysis of human dopaminergic neuroblastoma cells after RNA interference of SNCA-a key player in the pathogenesis of Parkinson's disease. Brain Res 1256:19-33

55. Palacino JJ, Sagi D, Goldberg MS, Krauss S, Motz C, Wacker M, Klose J, Shen J (2004) Mitochondrial dysfunction and oxidative damage in parkin-deficient mice. J Biol Chem 279:18614-18622

56. Chen F, Wollmer MA, Hoerndli F, Munch G, Kuhla B, Rogaev EI, Tsolaki M, Papassotiropoulos A, Gotz J (2004) Role for glyoxalase I in Alzheimer's disease. Proc Natl Acad Sci USA 101:7687-7692

57. Munch G, Mayer S, Michaelis J, Hipkiss AR, Riederer P, Muller R, Neumann A, Schinzel R, Cunningham AM (1997) Influence of advanced glycation end-products and AGE-inhibitors on nucleation-dependent polymerization of beta-amyloid peptide. Biochim Biophys Acta 1360:17-29

58. Munch G, Thome J, Foley P, Schinzel R, Riederer P (1997) Advanced glycation endproducts in ageing and Alzheimer's disease. Brain Res Brain Res Rev 23:134-143

59. Kallhoff V, Peethumnongsin E, Zheng H (2007) Lack of alphasynuclein increases amyloid plaque accumulation in a transgenic mouse model of Alzheimer's disease. Mol Neurodegener 2:6

60. Krautwald M, Munch G (2010) Advanced glycation end products as biomarkers and gerontotoxins - a basis to explore methylglyoxal-lowering agents for Alzheimer's disease? Exp Gerontol [Epub ahead of print]

61. Dias WB, Hart GW (2007) O-GlcNAc modification in diabetes and Alzheimer's disease. Mol Biosyst 3:766-772

62. Leclerc E, Sturchler E, Vetter SW, Heizmann CW (2009) Crosstalk between calcium, amyloid beta and the receptor for advanced glycation endproducts in Alzheimer's disease. Rev Neurosci 20:95-110

63. Eugene E, Depienne C, Baulac S, Baulac M, Fritschy JM, Le Guern E, Miles R, Poncer JC (2007) GABA(A) receptor gamma 2 subunit mutations linked to human epileptic syndromes differentially affect phasic and tonic inhibition. J Neurosci 27: $14108-14116$

64. Thornalley PJ (2003) Protecting the genome: defence against nucleotide glycation and emerging role of glyoxalase I overexpression in multidrug resistance in cancer chemotherapy. Biochem Soc Trans 31:1372-1377

65. Villa T, Guthrie C (2005) The Isylp component of the NineTeen complex interacts with the ATPase Prp16p to regulate the fidelity of pre-mRNA splicing. Genes Dev 19:1894-1904 
66. Jang JH (2004) FIGC, a novel FGF-induced ubiquitin-protein ligase in gastric cancers. FEBS Lett 578:21-25

67. Budd ME, Campbell JL (1995) DNA polymerases required for repair of UV-induced damage in Saccharomyces cerevisiae. Mol Cell Biol 15:2173-2179

68. Syvaoja JE (1990) DNA polymerase epsilon: the latest member in the family of mammalian DNA polymerases. Bioessays 12: $533-536$
69. Forch P, Puig O, Kedersha N, Martinez C, Granneman S, Seraphin B, Anderson P, Valcarcel J (2000) The apoptosis-promoting factor TIA-1 is a regulator of alternative pre-mRNA splicing. Mol Cell 6:1089-1098

70. Tian Q, Streuli M, Saito H, Schlossman SF, Anderson P (1991) A polyadenylate binding protein localized to the granules of cytolytic lymphocytes induces DNA fragmentation in target cells. Cell 67:629-639 